\title{
ANALYSIS OF LEVEL OF AWARENESS AND USAGE OF SOCIAL MEDIA IN HEALTHCARE SECTOR IN TRICITY CHANDIGARH
}

\section{DR. RAMANDEEP SAINI \& MANISHA CHEEMA}

Dean, International Affairs, CGC Landran, Director-Principal, Chandigarh Business School of Administration, Landran, Mohali

Research Scholar,(I.K.Gujral Punjab Technical University), Assistant Professor, Chandigarh Business School of Administration, Landran, Mohali

\begin{abstract}
Digital marketing has changed the shape of advertisement. Social media, one of the popular tool of digital marketing is extensively utilized in various sectors. Though it looks challenging in some of the sectors like healthcare sector. Social media has given an opportunity to the marketers to spread awareness about various services offered by the healthcare service providers. Marketers can connect to the customers and are able to manage their relationship with them. It also helps to attract more customers and enables customers to be co-producer of services. According to ICUBE report 2018, India had 483 million internet users (growth of 18\%) and was expected to be 627 million by 2019. This figure is projected to grow to 666.4 million internet users in 2023. According to study, the number of social media users in India stood at 326.1 million in 2018 and is expected to grow to 448 million by 2021. A social media user in India spends averagely 17 hours per week on social media. This rapidly increasing awareness of social media in India shows the more prospects of advertisement to the marketers. This research paper aims to analyse the difference in the level of awareness and usage of social media in healthcare services by social media users in tricity (Chandigarh, Mohali and Panchkula). The study was done by randomly selecting 130 respondents from each city through structured questionnaire.
\end{abstract}

KEYWORDS: e-health, consumer awareness, usage of social media, healthcare service providers

Received: Jun 08, 2020; Accepted: Jun 28, 2020; Published: Sep 15, 2020; Paper Id.: IJMPERDJUN20201247

\section{LITERATURE REVIEW}

Social networking sites, a fringe of technology has made it easier for marketers to extend their campaigns to their consumers. According to Chi(2011,46),marketers through social media connects the brand and the consumers between brands and consumers as it offers a personal channel to users for social interaction so they have to learn to incorporate the social media effectively in their business plan. (Mangold and Faulds 2099).It can be used to gain a competitive advantage.

Social media needs to be understood extensively by the marketer to maximise the benefits from it.He needs to understand the level of participation of consumer on www. According to Kaplan and Haenlein 2010,consumeriscontinuouslyalteringthecontentonwebsites.Technologyhasmadehimeffectiveco- producer. $\mathrm{He}$ is interactive and is an active operator and can add value to the wedsite if he is made capable to do so(Campbell et al.

2011). According to Kaplan and Haenlein (2010) and Sinclaire and Vogus(2011),socialmediaisbasedonideologicalandtechnologicalsoftwarefoundationswherecertain applications create and generate content. But these require a specific skill to understanding and interact on virtual world of social 
media. They need to understand how to connect with others on this invisible media. Consumer needs to be aware of latter and know how to join social groups based on their varied interestsandneedlikeentertainment,law,finance,consultancy,politics,sports,healthcareetc.(Ellison, Steinfield \& Lampe, 2007; Lenhart \& Madden, 2007; Boyd \& Ellison, 2007 as cited in Cox 2010). Marketer must understand the level of knowledge consumer has of usage of socialmedia.

AccordingtoKaplanandHaenlein2010,It'saplatformwhereparticipantscancreatetheirownprofiles and give access and to their friends to view their profiles. They can form network to exchange and dissipate information. According to Mady 2011, consumer must embrace technology i.e. social media to for the marketer to accomplish goals through compaign. Consumer's awareness and his readiness to usage of social media is important for marketer.It helps marketer's to remain in touch with their consumers to support consumers in decision making.Marketers can motivate them through repurchase the products (Shankar et al. 2011, 29). Marketers have used social sites to get connected to consumers in all varied verticals. Healthcare service providers have also used social media for marketing campaign.According to Finch F, Mort, M.; May, C.; Mair(2005)and Kelly, L.; Jenkinson, Ziebland, (2013),thepatientsperceptionarechangingwithtechnologyinhealthcaresectoranduserfriendlysites and labels on sites shown on social sites have affected patient-health professional relationships and his participationhasimprovisedservesinhealthcare.Soithasbecomemandatoryforthemarketerstoknow of awareness and usage of social sites for the healthcaresector.

The paper is focused on consumer's awareness and ability to use social media on healthcare services. Marketing through social media has been studied only in experimental and theoretical research context but consumer awareness and its usage hasn't been studied in healthcare sector.

\section{OBJECTIVES}

H01 : There is no significant difference in level of consumer awareness towards social media on healthcare service sector based on Tricity Chandigarh.

$\mathrm{H}_{02}$ : There is no significant difference in the level of consumer access to social media in healthcare service sector based on Tricity Chandigarh.

$\mathrm{H}_{03}$ : There is no significant difference in level of usage of social media by consumers in healthcare service sector based on Tricity Chandigarh

\section{RESEARCH METHODOLOGY}

The study was done under demographic (age \& gender) in Tricity(Chandigarh). convenience sampling method was employed. Primary Data was collected personally and through email 390 consumersthroughthroughastructuredquestionnaire.Oftheserespondents, 130fromeachcity

i.e. Chandigarh, Panchkula and Mohali were taken. Primary data was collected personally and through email. SPSS was used to analyse the data.

\section{Data Analysis}




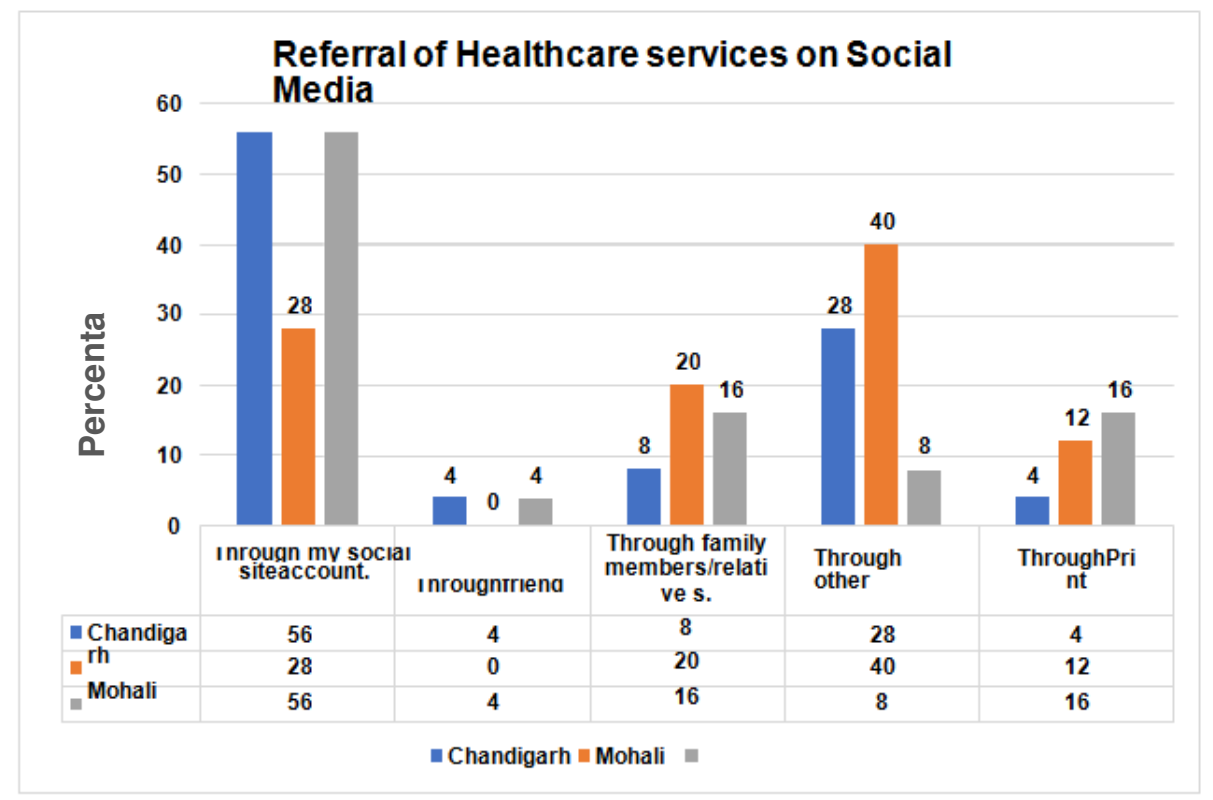

Figure 1

$56 \%$ of referral are from social site in Chandigarh and Panchkula and is found to be only $28 \%$ in Mohali. $4 \%$ are through friends in Chandigarh and Panchkula and none is found to be from inMohalithroughfriends.Referralsarefoundtobemax(40\%)throughotherinternetresources in Mohali and $16 \%$ is maximum in Panchkula through PrintMedia.

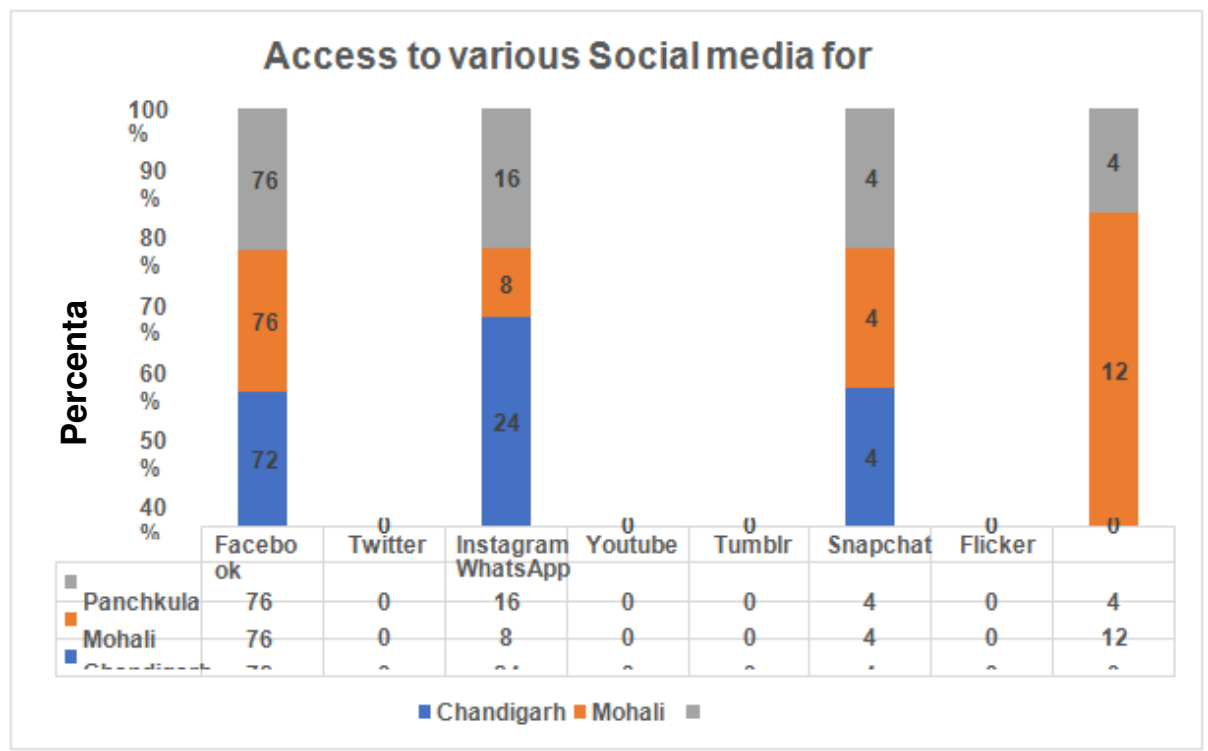

Figure 2

Facebook users are maximum and equal in Mohali and Panchkula i.e. 76\%,Instagram user are maximum in Chandigarh i.e. 24\%,WhatsApp users are maximum in Mohali i.e.12\%. Thereare no user who accesses from Tricity on Twitter, youTube, Tumblr and flicker forhealthcare. 


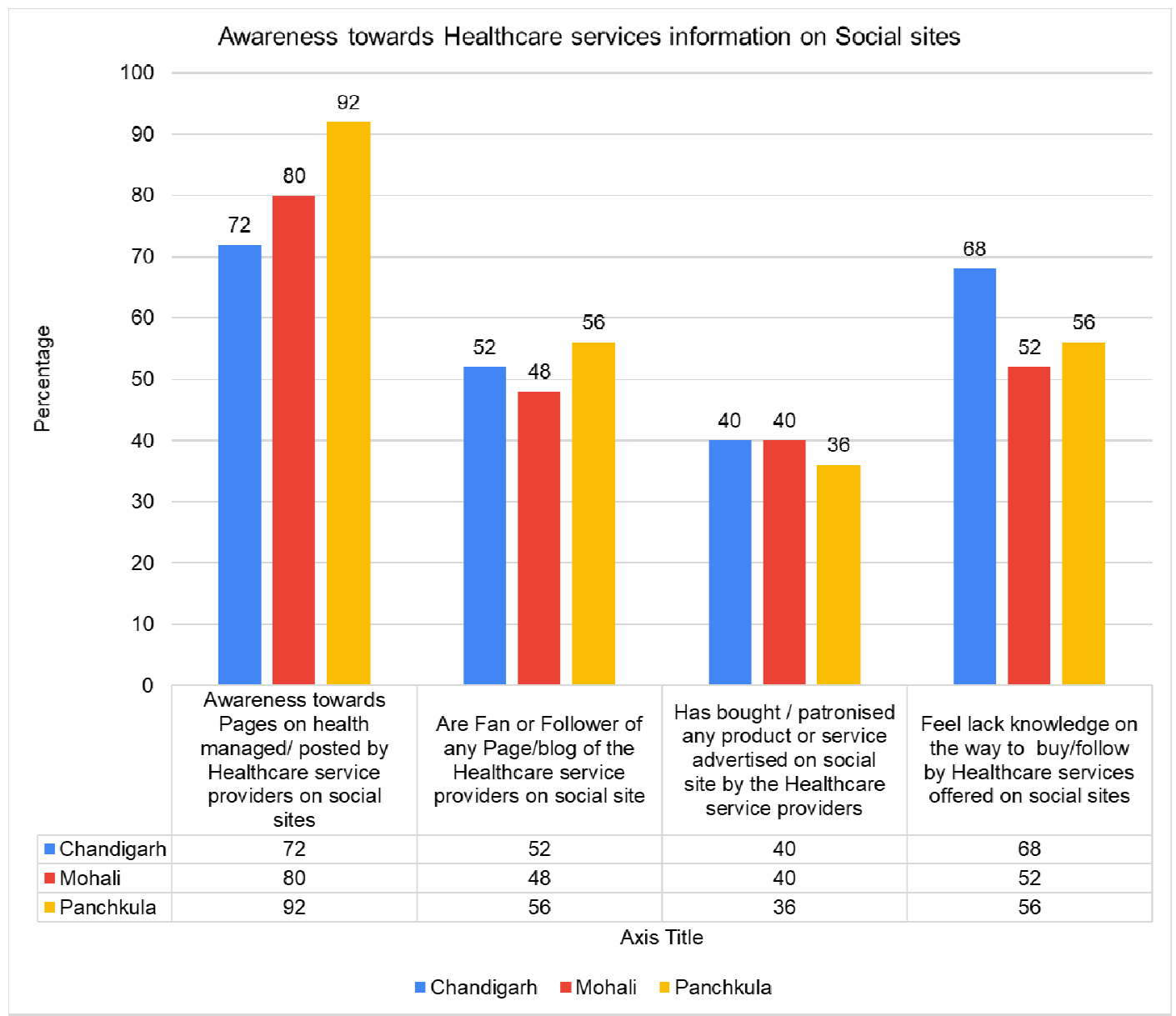

Figure 3

Respondents' awareness towards Pages on health managed/ posted by Healthcare Service Providersonsocialsiteshasfoundtobe92\% maximuminPanchukulaand72\%inChandigarh. Respondents that are Fan or Follower of any Page/blog of the Healthcare Service Providers on social site has found to be 56\% maximum in Panchukula and $48 \%$ in Mohali. Respondentsthat Hasbought/patronisedanyproductorserviceadvertisedonsocialsitebytheHealthcareService Providers has found to be $40 \%$ maximum and equal in Chandigarh and Mohali and $36 \quad \%$ Panchukula.Respondentsthatfeellackknowledgeonthewaytobuy/followbyHealthcare services offered on social sites has found to be $68 \%$ maximum in Chandigarh and $52 \%$ in Mohali. 


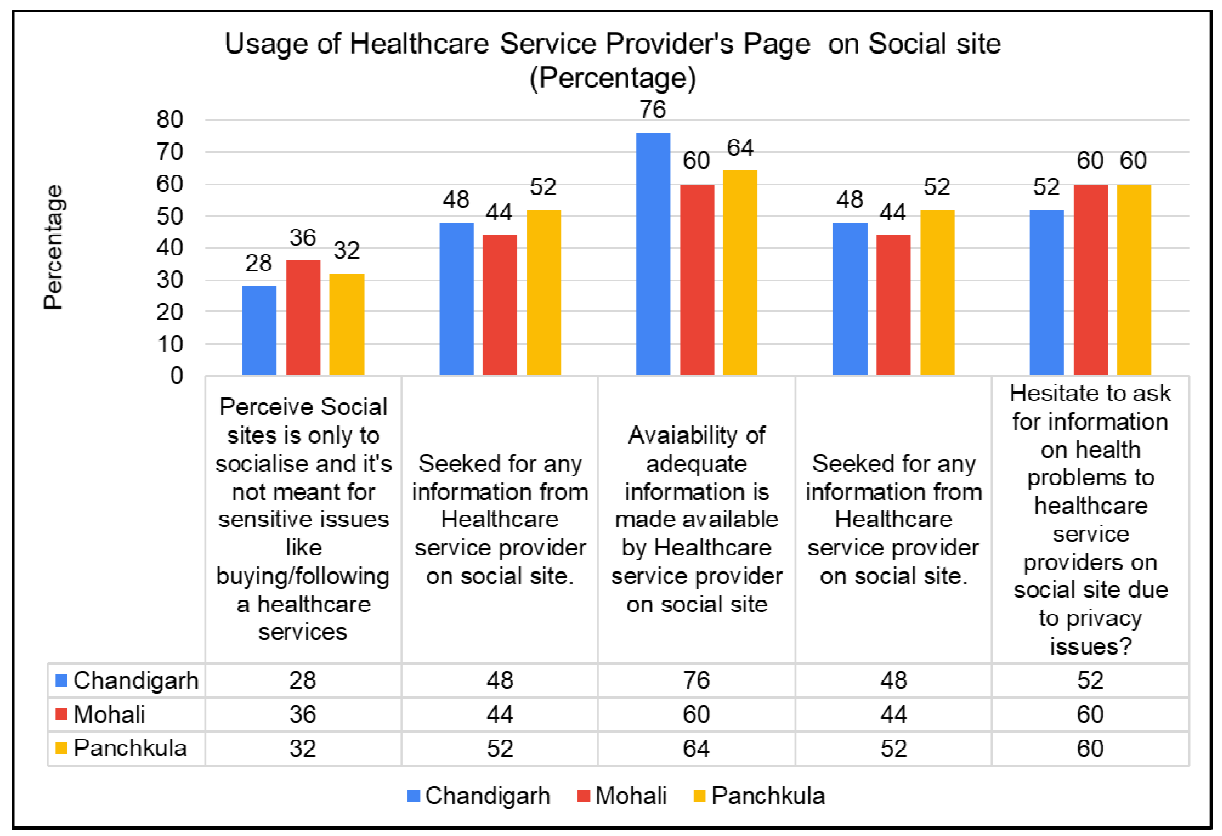

Figure 4

RespondentsthatPerceiveSocialsitesisonlytosocialiseandit'snotmeantforsensitiveissues like buying/following a healthcare services has found to be $36 \%$ maximum in Mohali and28\% in Chandigarh. Respondents that have seeked for any information from Healthcare service provideronsocialsite.\%hasfoundtobe52maximuminPanchukulaand44\%inMohali. Respondents that Avaiability of adequate information is made available by Healthcare service provider on social site has found to be $76 \%$ maximum in Chandigarh and $60 \%$ in Mohali. Respondents that Seeked for any information from Healthcare service provider on social site. has found to be 52\% maximum in Panchukula and 44\% in Mohali. Respondents that Hesitate to ask for information on health problems to healthcare service providers on social site due to privacy issues? has found to be $60 \%$ maximum and equal in Mohali \& Panchukula and 52\%in Chandigarh.

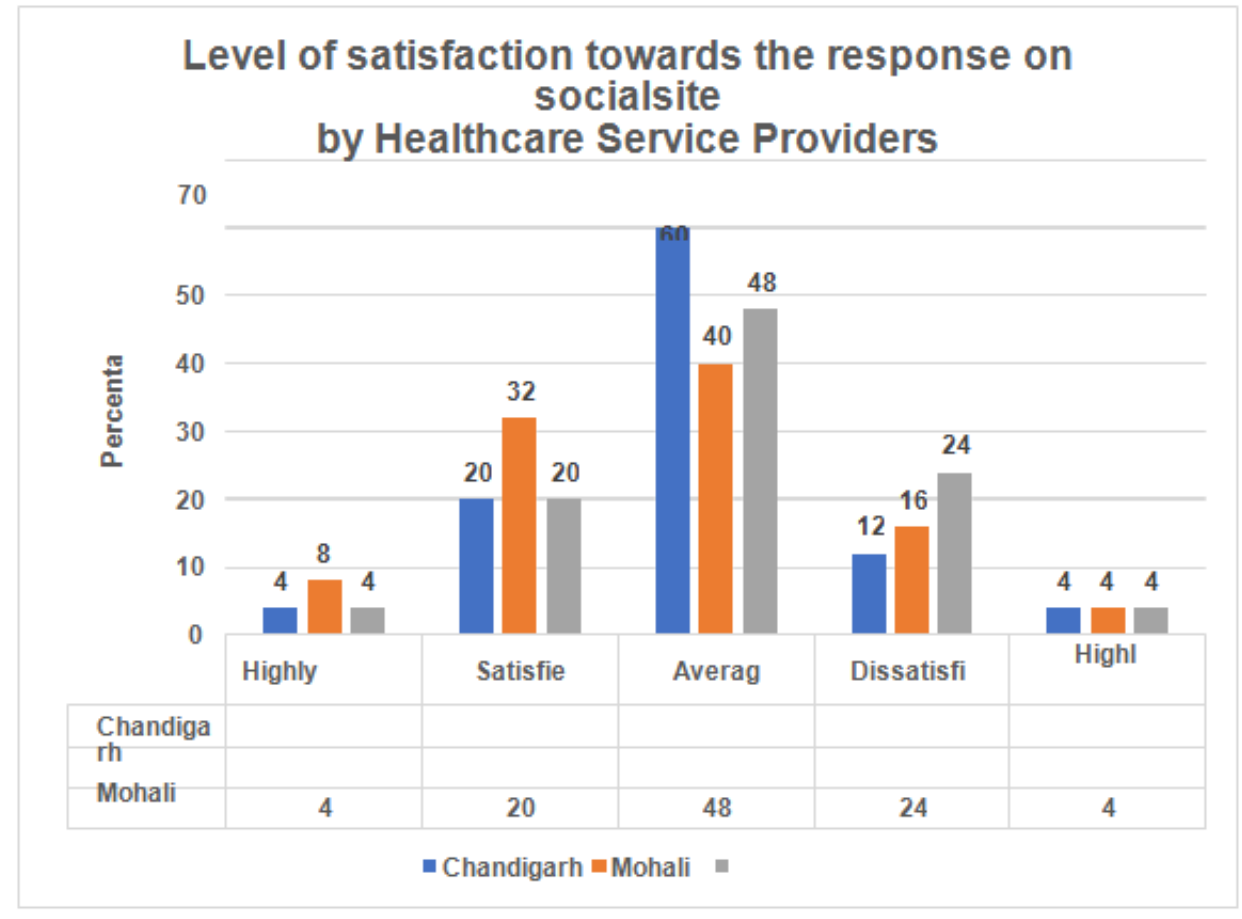


Figure 5

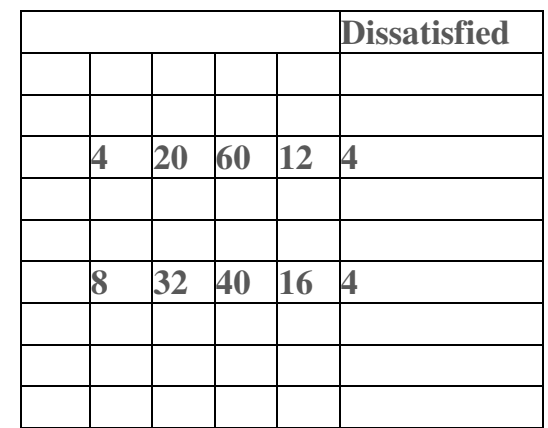

\begin{tabular}{|c|c|c|c|}
\hline $\begin{array}{l}32 \% \text { and } 8 \% \text { aretherespondentsfromMohaliwhoa } \\
\text { resatisfiedorhighlysatisfiedwithresponse of } \\
\text { response from social site by Healthcare Service } \\
\text { Providers. } 24 \% \text { are the respondents from } \\
\text { Panchkula who are maximum dissatisfied with } \\
\text { response of response from social site by } \\
\text { Healthcare Service Providers where as level of } \\
\text { highly dissatisfied is same for tricity i.e.4\% } \\
\text { Dependent Variable }\end{array}$ & (I) Location & (J) Location & Sig. \\
\hline \multirow{3}{*}{$\begin{array}{l}\text { Respondent is aware of information on } \\
\text { Healthcare product/service on social Media. }\end{array}$} & \multirow{2}{*}{ Chandigarh } & Mohali & .733 \\
\hline & & Panchkula & .525 \\
\hline & Mohali & Panchkula & .937 \\
\hline \multirow{3}{*}{$\begin{array}{l}\text { Respondent is a Fan or Follower ofany of the } \\
\text { Healthcare service providers on socialMedia. }\end{array}$} & \multirow{2}{*}{ Chandigarh } & Mohali & 1.000 \\
\hline & & Panchkula & .422 \\
\hline & Mohali & Panchkula & .466 \\
\hline \multirow{3}{*}{$\begin{array}{l}\text { Respondenthasbought/patronisedany product or } \\
\text { service advertised on social media by the } \\
\text { Healthcare service providers. }\end{array}$} & \multirow{2}{*}{ Chandigarh } & Mohali & .862 \\
\hline & & Panchkula & .397 \\
\hline & Mohali & Panchkula & .220 \\
\hline \multirow{3}{*}{$\begin{array}{l}\text { Respondent feels lack knowledge on the way to } \\
\text { buy/follow by Healthcare services offered on } \\
\text { social media. }\end{array}$} & \multirow{2}{*}{ Chandigarh } & Mohali & .284 \\
\hline & & Panchkula & .926 \\
\hline & Mohali & Panchkula & .203 \\
\hline \multirow{3}{*}{$\begin{array}{l}\text { Respondent feels social media is onlyto } \\
\text { socialise and it's not meant for sensitive issues } \\
\text { like buying/followinga healthcareservices. }\end{array}$} & \multirow{2}{*}{ Chandigarh } & Mohali & 1.000 \\
\hline & & Panchkula & .926 \\
\hline & Mohali & Panchkula & .934 \\
\hline \multirow{3}{*}{$\begin{array}{l}\text { Respondent gets adequate information is made } \\
\text { available by Healthcareservice provider on } \\
\text { socialmedia. }\end{array}$} & \multirow{2}{*}{ Chandigarh } & Mohali & .659 \\
\hline & & Panchkula & .965 \\
\hline & Mohali & Panchkula & .843 \\
\hline \multirow{5}{*}{$\begin{array}{l}\text { Respondent has ever asked for any information } \\
\text { from Healthcare service provider on social } \\
\text { media.. }\end{array}$} & \multirow{2}{*}{ Chandigarh } & Mohali & 1.000 \\
\hline & & Panchkula & .422 \\
\hline & Mohali & Panchkula & .466 \\
\hline & \multirow{2}{*}{ Chandigarh } & Mohali & .528 \\
\hline & & Panchkula & .337 \\
\hline $\begin{array}{l}\text { Respondent is satisfied with usage of social } \\
\text { media in Healthcare products/services. }\end{array}$ & Mohali & Panchkula & .068 \\
\hline \multirow{3}{*}{$\begin{array}{l}\text { Respondent hesitates to ask for information on } \\
\text { health problems to healthcare service providers } \\
\text { on social media due to privacy issues. }\end{array}$} & \multirow{2}{*}{ Chandigarh } & Mohali & .831 \\
\hline & & Panchkula & .006 \\
\hline & Mohali & Panchkula & .036 \\
\hline
\end{tabular}

There is no significant difference in level of awareness of information on healthcare product/service on social media, access as a Fan or Follower of any of the Healthcare service providersonsocialMedia,responseastobuyorpatroniseanyproductorserviceadvertisedon social media by the Healthcare 
service providers ans lack knowledge on the way to buy/follow by Healthcare services offered on social media, seeking for information and availability of adequate information on healthcare on social media.There is no significant difference in perception of social media is only to socialise and it's not meant for sensitive issues like buying/following a healthcare services.There is no significant difference in level on usage of social media in Healthcare sector between Chandigarh \& Mohali(sig.=.831). a but significant difference w.r.t. Panchkula \& Mohali(sig.=.036). and Panchkula \& Chandigarh(sig.=.006).But there's a significant difference in level of hesitation to ask for information on health problems to healthcare service providers on social media due to privacy issues between Chandigarh \& Mohali(sig.=.831). a but significant difference w.r.t. Panchkula \& Mohali(sig.=.036). and Panchkula \&Chandigarh(sig.=.006).

\section{CONCLUSIONS}

Our findings is providing insight into consumer awareness, access and usage towards social media for healthcare services based on Tricity Chandigarh. Healthcare service providers needs to aware consumers of access and usage of social media to seek information on healthcare services. The initiatives should be taken to educate them. It will help marketer to achieve their objective through social marketing campaign.It also strengths the relation between marketerand consumer. Consumers' usage of social media also helps to engage them in co-creation of services.Marketershoulddevelopandbringattractiveandcreativepagesonhealthcareservices to aware and spread information forconsumers.

\section{REFERENCES}

1. Boyd, d., \& Ellison, N. (2007). Social network sites: Definition, history, and schola rship. Journal of Computer Mediated Communication $13,210 \square 230$.

2. Chi, Hsu-Hsien. 2011. “Interactive Digital Advertising VS. Virtual Brand Community: Exploratory Study of User Motivation and Social Media Marketing Responses in Taiwan.” Journal of Interactive Advertising 12:44-61.

3. Campbell, Colin, Leyland F. Pitt, Michael Parent, and Pierre R. Berthon. 2011. "Understanding Consumer Conversations around Ads in a Web 2.0 World." Journal of Advertising40:87-102.

4. Finch, T.; Mort, M.; May, C.; Mair, F. Telecare: Perspectives on the changing role of patients and citizens.J. Telemed. Telecare 2005, 11,51-53

5. Lampe, C., Ellison, N., \& Steinfield, C. (2007). A familiar face(book): Profile elem ents as signals in an online social network. In Proceedings of the SIGCHI conferen ce on human factors in computing systems (pp. 435-444). New York:ACM.

6. Kaplan, Andreas M. and Michael Haenlein. 2010. “Users of the World, Unite! The Challenges and Opportunities of Social Media.” Business Horizons 53:59-68.

7. Kelly, L.; Jenkinson, C.; Ziebland, S. Measuring the effects of online health information for patients: Item generation for an e-health impact questionnaire. Patient Educ. Couns. 2013, 93,433-438.

8. Lenhart, A. Madden, M. (2007). Teens, privacy, and online social networks: How t eens manage their online identities and personal information in the age ofMySpac Pew Internet \& American Life Project. http://www.pewinternet.org/Reports/200 7/Teens. Privacy-and.Online-Social-Networks.aspx

9. Mady,TarekT.2011. "Sentimenttowardmarketing:Shouldwecareaboutconsumer alienationandreadinesstousetechnology?.”JournalofConsumerBehavior10:192- 204

10. Mangold, Glynn W., and David J. Faulds. 2009. “Social Media: The New Hybrid Element of the Promotion Mix.” Business Horizons 52:357365 .

11. Sinclaire, Jollean K. and Clinton E. Vogus. 2011. "Adoption of social networking sites: an exploratory adaptive structuration perspective for global organizations.” InformationTechnologyManagement12:293-314,DOI10.1007/s10799-011-0086- 5. 
12. Shankar,Venkatesh, Jeffery Inman, Murali Mantrala, Eileen Kelley, and Ross Rizley. 2011. "Innovations in Shopper Marketing: Current Insights and Future Research Issues.” Journal of Retailing 1:s29-s42,doi:10.1016/j.jretai.2011.04.007. 